STUDII

\title{
PACTELE ASUPRA UNEI SUCCESIUNI VIITOARE - 150 DE ANI DE SINGURĂTATE
}

DOI: 10.24193 /SUBBiur.65(2020).4.22

Ioana OLARU*

Rezumat: Acest articol analizează problematica pactelor asupra unor succesiuni viitoare din perspectivă istorică și a Regulamentului (UE) nr. 650/2012 al Parlamentului European și al Consiliului, din 4 iulie 2012, privind competența, legea aplicabilă, recunoaşterea şi executarea hotărârilor judecătoreşti şi acceptarea şi executarea actelor autentice în materie de succesiuni şi privind crearea unui certificat european de moștenitor. Scopul său este de a înțelege admisibilitatea acestor pacte în cauzele cu elemente de extraneitate în dreptul român și de a analiza dacă, anumite reglementări din dreptul intern, ar putea fi considerate pacte asupra unor succesiuni viitoare.

Cuvinte cheie: succesiune, pact asupra unei succesiuni viitoare, practică notarială, drept internațional privat.

* Dr. în drept, notar notar public în CNP București și formatoare la Institutul notarial român, ioanaolaru1@yahoo.com. 


\title{
AGREEMENTS AS TO SUCCESSION - 150 YEARS OF SOLITUDE
}

\begin{abstract}
This article examines the agreements as to succession from a historical perspective and in the context of the particular effects given by the Regulation (EU) no. 650/2012 of the European Parliament and of the Council of 4 July 2012 on jurisdiction, applicable law, recognition and enforcement of judgments and acceptance and enforcement of authentic instruments in matters of succession and on the creation of a European Certificate of Succession. The article aims to establish the content and the admissibility of these agreements in successions having cross-border implications that are governed by Romanian applicable law, and to determine which agreements allowed by Romanian civil law could fall under the European definition.
\end{abstract}

Keywords: succession, pact on a future succession, notarial practice, private international law.

\section{Cuprins}

I. Introducere în problematica pactelor asupra unei succesiuni viitoare ............. 752

II. Din istoria pactelor asupra succesiunilor nedeschise .......................... 754

III. Spre o contractualizare a dreptului succesoral în Europa post-modernă........... 759

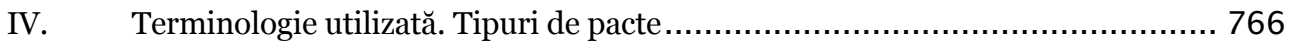

V. Conținutul noțiunii de pact asupra unei succesiuni viitoare în RES. .............. 771

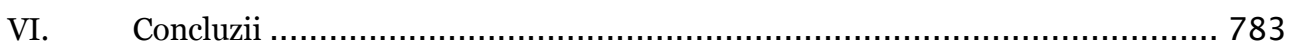




\section{Introducere în problematica pactelor asupra unei succesiuni viitoare}

Succesiunea contractuală pune în lumină diferențele care există în legislațiile succesorale ale statelor europene. De-a lungul timpului, regulile moralei, organizarea societății şi interesele politice au influențat utilizarea şi admisibilitatea pactelor succesorale. Însă principiile autonomiei de voință și a libertății contractuale au câștigat tot mai mult teren în materia succesiunilor, şubrezind tradiționala interdicție a pactelor asupra unei succesiuni viitoare. Din punctul de vedere al transmiterii succesorale, statele europene se împart tradițional în două categorii: cele ce nu prevăd transmiterea contractuală a succesiunii, şi cele ce admit transmiterea succesiunii atât ope legis, cât și în temeiul testamentului sau prin intermediul pactelor succesorale. Art. 955 C. civ. stabilește că patrimoniul defunctului se transmite prin moștenire legală, în măsura în care cel care lasă moștenirea nu a dispus altfel prin testament. Este astfel menținută reglementarea art. $650 \mathrm{C}$. civ. 1864, care excludea posibilitatea instituirii unui moștenitor prin intermediul unui contract. $\mathrm{Cu}$ toate acestea, spre deosebire de reglementarea actuală, Codul civil 1864 preluase din dreptul francez şi adaptase sub denumirea de donație de bunuri viitoare, un instrument juridic prin care soții sau unul dintre aceştia puteau fi desemnați irevocabil ca moștenitor, în forma prevăzută pentru contractul de căsătorie ${ }^{1}$. Această instituție avea să dispară o dată cu adoptarea Codului Familiei în anul 1954, fără a fi readusă la viață odată cu intrarea în vigoarea a noului Cod civil în octombrie 2010.

${ }^{1}$ Codicele Civil, adnotat cu jurisprudența română, Editura Tipografiei Gutenberg, București, 1894, p. 572 și p.573 
O etapă importantă pentru viziunea statelor asupra pactelor succesorale este deschisă la nivel european de aplicarea Regulamentului (UE) nr. 650/2012 al Parlamentului European și al Consiliului din 4 iulie 2012 privind competența, legea aplicabilă, recunoașterea și executarea hotărârilor judecătorești și acceptarea și executarea actelor autentice în materie de succesiuni şi privind crearea unui certificat european de moștenitor ${ }^{2}$, începând cu data de 17 august 2015, actul normativ având caracter obligatoriu în statele membre, în conformitate cu tratatele. Prin definiția dată succesiunii în art. 3 alin. (1) lit. a) $\mathrm{RES}^{3}$, normativul european recunoaşte cu titlu de principiu că transmisiunea succesiunii poate fi nu numai legală sau testamentară, dar și contractuală. Postulând cu privire la admisibilitatea succesiunii contractuale, actul normativ european definește termenii ce permit ca acest principiu să fie aplicat chiar şi în statele ce nu recunosc valabilitatea unei transmiteri succesorale contractuale în ordinea lor internă. Este creată o adevărată succesiune europeană, guvernată de reguli conflictuale, jurisdicționale și materiale ${ }^{4}$ particulare, ce ia naștere din momentul plasării situației de succesiune în domeniul de aplicare materială şi teritorială a RES. Cele mai importante elemente ale acestei succesiuni sunt definite ca noțiuni autonome, în mod uniform și obligatoriu pentru statele membre, interpretarea acestora fiind permisă doar Curții Europene de

2 Denumit în continuare RES, disponibil la adresa: https://eur-lex.europa.eu/legalcontent/RO/TXT/?uri=celex\%3A32012Ro650.

3 Art. 3 RES : „In sensul prezentului regulament: (a),succesiune” înseamnă succesiunea privind patrimoniul unei persoane decedate și acoperă orice formă de transfer de bunuri, drepturi și obligații pentru cauză de moarte, fie că este vorba de un act voluntar de transfer, sub forma unei dispoziții pentru cauză de moarte, fie de un transfer sub forma succesiunii ab intestat; (...)"

4 În RES sunt incluse și dispoziții de drept material: art. 31 privind adaptarea drepturilor reale, art. 32 privind comorienții și art. 33 privind succesiunile vacante. 
Justiție. Caracterul european al acestei succesiuni nu vine neapărat şi exhaustiv din plasarea unor elemente esențiale ale acesteia pe teritoriul statelor membre. Mai mult, nu se poate face o distincție clară între succesiunile pur europene și cele care conțin și elemente de conexitate cu statele terțe. Succesiunile în care defunctul avea ultima reședință obişnuită pe teritoriul unui stat membru sunt tratate la fel cu cele în care ultima reședință a acestuia era într-un stat terț. În acelaşi fel, normele RES se aplică și atunci când legea succesorală este cea a unui stat membru, dar şi atunci când legea succesorală este cea a unui stat terț. Punctul care leagă elementele diferite ale acestei succesiuni europene este competența internaţională a autorităţilor dintr-un stat membru de a hotărî cu privire la succesiune în ansamblul său. Prin adoptarea RES, statele membre acceptă, în anumite condiții, valabilitatea unei transmiteri contractuale a patrimoniului succesoral, chiar dacă lex successionis prevede dihotomia clasică în succesiune legală şi testamentară.

\section{Din istoria pactelor asupra succesiunilor nedeschise}

Dispoziţiile post mortem ne „(...) oferă cea mai convingătoare, mai sinceră şi mai pilduitoare expresie a ceea ce omul înțelege prin proprietate şi destinul ei." 5 Din utilizarea sau respingerea pactelor succesorale, din formele pe care acestea le îmbracă sau din legătura lor cu convențiile matrimoniale poate fi dedusă raportarea față de patrimoniu, dar şi față de moarte, a societății și individului.

5 Georgeta Filitti ( antolog., pref.), Testamente (1599-1917) - Antologie și studiu introductiv, Ed. Notarom, București, 2007, p.19. 
Deplina libertate de a testa fusese consacrată de Legea celor XII Table, însă legiuitorul roman intervenise treptat pentru a o limita prin reglementarea exheredărilor și a rezervei succesorale ${ }^{6}$. Ea fusese mai degrabă oferită pentru ca autorul să învingă frica de moarte 7 , consolat fiind în acest fel pentru caracterul inevitabil al acestui eveniment; justificarea ar putea să se găsească în credința romanilor că morții continuau să trăiască într-un tărâm paralel, inferior celui al viilor, motiv pentru care moștenitorilor le revenea, corelativ libertăţii dispunătorului, obligația fundamentală de a-i respecta voința. La polul opus, pactele succesorale presupuneau o adevărată renunțare a dispunătorului la libertatea sa de a testa, atunci când autorul succesiunii stabilea împreună cu succesibilii săi, din timpul vieții, de o manieră irevocabilă, modul în care urmau să fie transmise bunurile sale la deces. Din acest motiv dreptul roman interzicea prin decizii de speță toate pactele succesorale care aduceau atingere exercițiului neîngrădit al libertății de a testa. Când autorul dispunea fără să se oblige să își mențină voința până la deces şi păstra posibilitatea să o revoce până în ultimul moment al vieții, se putea considera că el nu încheiase un pact asupra unei succesiuni viitoare ${ }^{8}$, acordându-i-se efectele morits causa dorite. Cercetarea surselor romane de la Legea celor XII Table până la legislația lui Iustinian inclusiv duce la concluzia că succesiunea nu se deferea decât în temeiul legii sau a voinței unilaterale a lui de cuius, fiind interzis orice pact asupra unei succesiuni viitoare, atât abdicativ cât şi prin care se instituia un moștenitor, atât cu privire la

\footnotetext{
${ }^{6}$ Vladimir Hanga, Mircea Dan Bob, Curs de drept privat roman, Ed. Universul juridic, Ediția a III-a, 2009, p. 237, pct.12

7 Charles Bahurel, Les volontés des morts-Vouloir pour le temps où l'on ne sera plus, Ed. LGDJ, 2014, p. 6 și p.20

${ }^{8}$ Marc Péter, Etude sur le pacte succesoral, thèse de doctorat, Université Genève, 1897 no :D 267, disponibilă la: https://doi.org/10.13097/archive-ouverte/unige:27253, p.12.
} 
succesiunea unui autor, cât și cu privire la succesiunea unui terț̣9. Practica de a încheia asemenea pacte era însă abundentă în dreptul roman, fiind exceptate de la regula nulității donația cu rezerva uzufructului, pactul prin care se stabilea soarta dotei în caz de deces, pactum mutuae successionis care era permis militarilor, donația-partaj şi stipulația post-mortem autorizată de Iustinian $^{10}$.

În următoarea etapă istorică, viziunea asupra pactelor succesorale se schimbă, marcând validarea socială a individului prin moștenire și grija pentru conservarea patrimoniul familial. Pentru a evita constrângerile sau interdicțiile de a transmite succesiunea printr-un contract, dreptul cutumiar francez apelează la ideea că, spre deosebire de testament, care este un act unilateral și uneori arbitrar, convenția matrimonială este mai justă, fiind rezultatul negocierii între două familiii ${ }^{11}$. Bazându-se pe interesul apărării familiei ce urma să se constituie, stipulațiile succesorale sunt înglobate în convențiile matrimoniale, care se bucurau la rândul lor de o libertate deplină a conținutului. Ideea nu caracterizează doar Franța în Evul mediu timpuriu, ci şi alte regiuni europene. În Catalonia rurală, societatea se baza pe transmiterea patrimoniului gospodăriei către primul fiu născut, prin intermediul unui pact succesoral încheiat de cele mai multe ori în momentul în care acesta urma să se căsătorească, care era astfel inclus în convenţia dotală. Dispozițiile acesteia erau diverse, nu se limitau doar la clauzele privind dota soției sau la ipoteca ce garanta restituirea acesteia; puteau fi incluse

\footnotetext{
9 Marc Péter, idem, p.14.

10 Jean-Philippe Lévy, André Castaldo, Histoire du droit civil, Ed. Dalloz, 2e édition, 2010, p.1317, nota de subsol 1.

${ }^{11}$ Jean-Philippe Lévy, André Castaldo, idem, p.1318.
} 
clauze impuse de alți membri ai familiei ${ }^{12}$, ori veritabile dispoziții mortis causa prin care fiul era instituit ca moștenitor. La stabilirea conținutului pactului succesoral participau astfel mai multe generaţii: autorii succesiunii, instituitul, viitoarea soție sau chiar membrii familiei viitoarei soții.

Analiza sociologică a familiei din societățile rurale europene furnizează ideea că patrimoniul era cel care asigura legătura dintre generațiile diferite ale unei familii, chiar şi atunci când acesta era redus ca valoare. "Transmiterea familială, de ordin patrimonial, lega indivizii, chiar dacă, aşa cum au arătat antropologii, sistemele de transmitere a bunurilor şi modalitățile de locuire erau foarte diferite în regiunile Europei. ${ }^{{ }^{13}}$ Individul depindea de moștenirea primită, fiii dobândeau bunuri de la tați și fiicele aveau nevoie de dotă pentru a se căsători. Instituția dotei era cunoscută şi în vechile legiuiri române : Codul Calimach (art. 1623) și Codul Caragea( art. 12, partea a III-a, cap.16) ${ }^{14}$, dar instituirea soților ca moștenitori prin intermediul convenției matrimoniale apare ulterior, la adoptarea Codului civil 1864, după modelul Codului civil Napoleon. Revoluția Franceză nu putea însă să tolereze niciuna dintre instituțiile ce caracterizau epoca trecută, cu atât mai puțin cele care ar fi perpetuat dreptul de primogenitură și inegalitatea partajelor. Orice modalitate de transmitere contractuală a succesiunii a fost suprimată prin

\footnotetext{
12 Susana Navas Navarro, Freedom of Testation Versus Freedom to Enter Into Succession Agreements and Transaction Costs, în The Law of Succession: Testamentary Freedom, European Perspectives, Europa Law Publishing, 2011, p. 115

13 "La transmission familiale, d'ordre patrimonial, liait les individus, même si, comme l'ont montré les anthropologues, les systèmes de transmission des biens et les modalités de résidence étaient très différents selon les régions d'Europe. ", Martine Segalen, Familles: De quoi héritons-nous ?, în Identité(s) - L'individu, le groupe, la société, Catherine Halpern (dir.), Ed. Sciences Jumaines, 2016, p. 171

14 C. Hamangiu, I. Rosetti Bălănescu, Al. Băicoianu, Tratat de drept civil român, vol. III, Ed. All, 1998, p. 67, pct.142
} 
Decretul din 17 Nivose $^{15}$, iar Codul civil francez din 1804 exprimă principiul general al interzicerii pactelor asupra unei succesiuni viitoare în trei articole diferite: art. 791 C.civ.1804, art. 1600 C. civ. 1804 și art. 130 alin.2 C. civ. $1804^{16}$. Acest principiu este preluat în toate codurile europene ${ }^{17}$ ce s-au inspirat din codul civil napoleonian, inclusiv în Codul civil român.

În prezent, o dată cu devalorizarea patrimoniului moștenit în raport de poziția individului în societate, în epoca unui Self-Made-Man, ne putem întreba care ar fi argumentele ce pledează pentru menținerea interdicţiei pactelor asupra unei succesiuni viitoare? Cu siguranță, două evoluții majore pot fi reținute: slăbirea mizei economice a moștenirii ${ }^{18}$ și transformarea

15 Décret de la Convention nationale, du 17.e jour de nivôse, an second de la république française, une \& indivisible, relatif aux donations \& successions, p.96 și urm., disponibil la adresa:

https://books.google.ro/books?id=kZxbAAAAcAAJ\&printsec=frontcover\&hl=ro\&source=gbs ge su mmary $\mathrm{r} \& \mathrm{cad}=0 \# \mathrm{v}=$ onepage $\& \mathrm{q} \& \mathrm{f}=$ false 16 disponibil la adresa:

https://www.legifrance.gouv.fr/codes/texte lc/LEGITEXTooo006070721/1804-01-10.

17 Art. 458 C.civ.it. Divieto di patti successori: (1)Fatto salvo quanto disposto dagli articoli 768 bis e seguenti, è nulla ogni convenzione con cui taluno dispone della propria successione. $\grave{E}$ del pari nullo ogni atto col quale taluno dispone dei diritti che gli possono spettare su una successione non ancora aperta, o rinunzia ai medesimi(2). Codice Civile e Leggi Complementari, IV Edizione, Ed. Simone, 2006, p.117

"Art. 458 C. civ. it. Interzicerea pactelor succesorale: (1) Cu excepția dispozițiilor articolelor 768 bis și următoarele, este nulă orice convenție prin care o persoană dispune de propria succesiune. Este de asemenea nul orice act prin care o persoană dispune de drepturile ce i s-ar cuveni dintr-o succesiune nedeschisă, sau renunță la acestea.(2)." ( trad.n.)

Art. 1271.2 C.civ. sp.: "Sobre la herencia futura no se podrá, sin embargo, celebrar otros contratos que aquellos cuyo objeto sea practicar entre vivos la división de un caudal y otras disposiciones particionales, conforme a lo dispuesto en el artículo 1056».

"Art. 1271.2 C.civ. sp.: În ceea ce privește moștenirea viitoare, nu va fi posibil, totuși, să fie încheiate alte contracte decât cele care au ca obiect împărțirea între vii a unei proprietăţi sau alte dispoziții de împărțire, în conformitate cu prevederile artícolului 1056. )." ( trad.n.) 18 Jean-François Guillaume, Les aspects sociologiques de la transmission du patrimoine familial, în Nathalie Baugnet et Jean-François Taymans(eds.), Planification succesorale. Aspects civils et fiscaux, Ed. Bruylant, Louvain-la-Neuve, Belgia, 2008, p. 16-18 
strategiilor succesorale în strategii contractuale, liber consimțite. Am putea spune că pactul succesoral devine un instrument menit să asigure preponderent pacea familială, și numai în subsidiar să asigure soarta și bunăstarea moștenitorilor. Modul unilateral în care părinții organizează accesul la resursele materiale ale copiilor poate fi perceput de aceștia ca o injustiție, chiar la multă vreme după intrarea în vârsta adultă, având capacitatea de a declanșa episoade depresive și de a deteriora relațiile dintre frați și surori19. Spre deosebire de testament, în care moștenitorii regăsesc expresia autorității celui care dispune, pactul succesoral ar putea reflecta voința comună a celor implicați. O distribuție patrimonială armonioasă, făcută cu participarea celor îndreptățiți și a autorului lor, ar putea consolida legăturile de familie și ar îmbunătăți raporturile dintre co-moștenitori. Din punct de vedere psihologic, transmiterea bunurilor familiale prin moștenire nu mai este un act pasiv, ci o manifestare activă a dobândirii, un proces în decursul căruia fiecare își poate găsi răspunsul la întrebarea: Ce fel de fiu/fiică/moștenitor/sunt/am fost eu? ${ }^{20}$

\section{Spre o contractualizare a dreptului succesoral în Europa post-modernă}

Sistemele succesorale în Europa se prezintă diverse atât în ceea ce privește validitatea testamentelor reciproce și conjunctive, cât și în ceea ce

\footnotetext{
19 Evelyne Favart, La transmission familiale : s'approprier le passé familial entre frères et sœurs, Revista Pensée Pluriels, 1/2006, no.11, p.89, disponibil la adresa: https://www.cairn.info/revue-pensee-plurielle-2006-1-page-83.htm.

20 Florence Calicis, Les héritages familiaux : comment faire avec nos loyautés ?, Revista Cahiers de psychologie clinique, 2014/2, no.43, p.86, disponibil la: https://www.cairn.info/revue-cahiers-de-psychologie-clinique-2014-2-page-81.htm
} 
privește admisibilitatea pactelor succesorale. Și Regulamentul european privind succesiunile reunește problematica testamentelor reciproce cu cea a pactelor asupra unei succesiuni viitoare, prin definirea noțiunii cadru de dispoziție pentru cauză de moarte. În dreptul german (§2265 BGB) numai soților le este permis să încheie un testament conjunctiv, care poate conține fie dispoziții independente unele de altele, fie dispoziții reciproce (\$2270 BGB $)^{21}$. Caracterul reciproc al dispozițiilor din testamentul conjunctiv produce efecte particulare atunci când testamentul unuia dintre soți este contestat sau declarat nul, legatele sau desemnările de moștenitori făcute de celălalt soț urmând aceeaşi soartă22 ${ }^{22}$ actul anulat. Testamentul conjunctiv nu este accesibil viitorilor soți, dar un cuplu logodit poate încheia o convenție matrimonială precum și un contract succesoral, care vor produce efecte după încheierea căsătoriei ( §1408, §2274, §2275 BGB).

Dimpotrivă, art. 968 C.civ fr. ${ }^{23}$, art. 589 C.civ. it. ${ }^{24}$, art. 669 C.civ. sp. ${ }^{25}$ şi art. 2181 C.civ. portughez ${ }^{26} \mathrm{nu}$ permit încheierea unor testamente conjunctive, nici dacă ar fi vorba de dispoziții reciproce, nici dacă ar fi gratificată o terță persoană. Pe de altă parte, soarta contractelor succesorale este şi ea diferită în funcție de statul în care acestea sunt încheiate. Codul civil

\footnotetext{
21 Disponibil la adresa https://www.gesetze-im-

internet.de/englisch bgb/englisch bgb.html\#p7521.

22 Peter Gottwald, Dieter Schwabm Eva Bütner, Family \& Succession Law in Germany, Ed. C.h.Beck, München, 2001, p. 132, pct.361 și 362.

23 Disponibil la adresa:

https://www.legifrance.gouv.fr/codes/section lc/LEGITEXTooooo6070721/LEGISCTA0oo 006150547? etatTexte=VIGUEUR\&etatTexte=VIGUEUR DIFF\#LEGIARTIoo0006434040.

24 Disponibil la adresa: https://www.brocardi.it/codice-civile/libro-secondo/titolo-iii/capoi/art589.html.

25 Disponibil la adresa: https://www.boe.es/eli/es/rd/1889/07/24/(1)/con/

26 Disponibil la adresa: https://dre.pt/web/guest/legislacao-consolidada//lc/123928118/202008292026/73749770/diploma/indice.
} 
german validează, potrivit §2275 BGB, instituirea de moștenitor prin intermediul unui contract succesoral; consecința încheierii unui asemenea act este aceea că dispunătorul nu mai poate întocmi nicio dispoziție posterioară pentru cauză de moarte, dar păstrează libertatea de a încheia acte cu titlu oneros (§2286BGB, §2289 BGB) şi donații, în afară de cazul în care acestea din urmă ar fi făcute cu rea credință (§§2286ff). Contractul succesoral astfel încheiat nu poate fi revocat unilateral şi urmează în toate celelalte aspecte regulile generale ale contractelor, iar pentru protecția dispunătorului este obligatorie forma notarială ( $\$ 2276$ BGB $)^{27}$. Și în dreptul austriac ${ }^{28}$ posibilitatea de a încheia un pact succesoral este rezervată soților, sau viitorilor soți sub condiția încheierii căsătoriei (\$1249 ABGB), pe când partenerii dintr-un un parteneriat înregistrat pot beneficia doar de anticiparea succesorală prin intermediul testamentului reciproc ( $\$ 1248$ ABGB).

Spre deosebire de acestea, sistemele de drept civil inspirate din Codul civil napoleonian au consacrat şi păstrat principiul de a interzice orice stipulație privind o succesiune nedeschisă. Însă, prin modificări succesive ce debutează în primul deceniu al secolului al XXI-lea, domeniul de aplicare a acestei prohibiții se reduce. În Belgia, prin Legea nr. 25 din 13.07.2017, intrată în vigoare la data de 01.09.2018, este introdus un titlu nou, dedicat pactelor succesorale. Noul art.1100/1 C. civ. be. ${ }^{29}$ interzice încheierea pactelor asupra unei succesiuni nedeschise, atât a celor privind succesiunea autorului cât și

\footnotetext{
27 Peter Gottwald, Dieter Schwabm Eva Bütner, op.cit., p. 134-135

28 Disponibil la adresa: https://e-justice.europa.eu/content general information-166-atfr.do?member $=1 \#$ toc 3 .

29
}

http://www.ejustice.just.fgov.be/cgi loi/change lg.pl?language=fr\&la=F\&cn=1804032132\& table name $=$ loi. 
cea a unui terţ, atât constitutive cât și abdicative, oneroase sau cu titlu gratuit, cu excepția celor pe care dispozițiile codului le permit în mod expres. Un nou tip de pact este introdus prin art. 1100/7 C.civ.be. Denumit pact succesoral global, acesta nu poate fi încheiat decât de părinți împreună cu toți descendenții în linie dreaptă, acestora din urmă fiindu-le permis să renunțe prin introducerea în drepturile sale a tuturor descendenților săi. Și prezumția de gratuitate a unei înstrăinări oneroase făcute cu rezerva unui drept de uzufruct, abitație sau rentă viageră este reformată, în prezent articolul ce o reglementează (art. 918 C.civ.be ${ }^{30}$ ) creând un adevărat pact succesoral punctual. Ca urmare a acestei modificări, nicio prezumție de gratuitate nu mai operează în cazul anumitor tipuri de înstrăinări. Oricare dintre moștenitorii rezervatari poate să renunțe unilateral, pro parte, la acțiunea în reducțiune, printr-o declarație conținută în contractul de donație sau printr-un act separat, ulterior donației, dar încheiat înainte de decesul autorului. Pactul Valkeniers, ce fusese admisibil și anterior acestor modificări, beneficiază de o nouă reglementare în art. 1388 alin.2 C.civ. be. ${ }^{31}$. Prin intermediul acestuia, soțul care are descendenți dintr-o relaţie anterioară sau adoptaţi anterior încheierii căsătoriei, poate să renunțe la rezerva sa succesorală abstractă, respectând formele prevăzute pentru încheierea sua modificarea convențiilor matrimoniale. Formalismul impus de art. 1100/5 C.civ.be guvernează toate tipurile de pacte prevăzute ca valabile. Regulile speciale de formă nu se

30

http://www.ejustice.just.fgov.be/cgi loi/change lg.pl?language=fr\&la $=F \& c n=1804032132 \&$ table name=loi.

31

http://www.ejustice.just.fgov.be/cgi loi/change lg.pl?language=fr\&la $=F \& c n=1804032133 \&$ table name=loi. 
limitează la întocmirea unui act notarial ${ }^{22}$, ci prescriu o procedură complexă atât pentru transmiterea proiectului de pact tuturor părțiilor, cât și pentru negocierea și discutarea conținutului actului, până la semnarea pactului întrun termen suficient de mare ca să permită o informare și o reflecție a celor implicați cu privire la consecințele produse. Garanția respectării drepturilor părților şi a informării lor complete este asigurată atât prin posibilitatea unor întrevederi explicative a persoanelor cu notarul instrumentator, cât şi prin facultatea conferită oricăreia dintre acestea de a fi însoțită de un alt notar propriu în procedura de încheiere a pactului. Această procedura complexă, actul notarial și garanțiile oferite părților au făcut ca noile pacte succesorale să se bucure de un real succes, în numai doi ani de la reformă fiind încheiate peste 1000 de asemenea pacte 33 . Modificarea dreptului succesoral belgian nu aduce o liberalizare a pactelor succesorale, ci doar o lărgire a domeniului excepțiilor de la interdicția pactelor asupra unei succesiuni viitoare, pactele fiind în continuare lipsite de o definiție cadru, dată într-o manieră pozitivă $\breve{3}^{34}$. În Italia, introducerea instituției denumită patto di famiglia a fost salutată ca o adevărată excepție de la principiul interdicției pactelor succesorale instituit de art. 458 C.civ.it. Legea nr. 55/200635 prin care este modificat Codul civil italian reușeşte să armonizeze vechea interdicție a pactelor succesorale cu

$3^{2}$ Art. 1100/5 C.civ. be: $[1 \S 1$ 1er. Tout pacte successoral est contenu dans un acte notarié., disponibil la

adresa: http://www.ejustice.just.fgov.be/cgi loi/change lg.pl?language $=$ fr\&la $=F \& c n=1804032132 \&$ table name $=$ loi.

33 https://www.notaire.be/nouveautes/detail/deja-1-ooo-pactes-familiaux-conclus-sur-desfutures-successions

34 Vincent Wyart, Les pactes sur succession future, în Pierre Moreau ( dir.), La réforme du droit des successions, Ed. Larcier, Bruxelles,2018, p. 279

35 Legge 14 febbraio 2006, n. 55 "Modifiche al codice civile in materia di patto di famiglia ",publicată în Gazzetta Ufficiale n. 50 din 1.03.2006, disponibilă la adresa: https://www.camera.it/parlam/leggi/060551.htm.

\section{3}


libertatea testamentară şi să păstreze proporția dintre rezerva succesorală și cotitatea disponibilă. Însă, scopul acesteia nu fusese acela de a produce o adevărată reformă în materia pactelor succesorale, ci mai degrabă promovase o măsură economică necesară pentru supraviețuirea companiilor mici și medii ${ }^{6}$ : desemnarea de către proprietarul în viață a aceluia sau acelora dintre descendenții săi care vor continua să conducă și să dețină afacerea familială. Nici în Franța nu s-a produs o schimbare de paradigmă în materia pactelor succesorale, chiar dacă dreptul succesiunilor şi liberalităţilor a trecut prin mai multe legi modificatoare ${ }^{37}$. Nu au avut câștig de cauză nici practicienii, care au susținut $3^{8}$ abrogarea interdicției și validarea pactelor asupra succesiunilor viitoare cu titlu general, cu condiția ca actul să presupună acordul autorului succesiunii, dat în formă autentică. Interdicția ce lovește pactele asupra unei succesiuni viitoare a fost menținută în Codul civil francez, chiar dacă textele ce o reglementează au primit o redactare nouă și o lărgire a numărului de excepții. Din materia contractuală, unde se găsea inițial (art. 1130 C.civ.180439), interdicția a fost plasată ca articol de debut al materiei succesorale ( art. 722 C.civ. fr..$^{40}$ ): toate convențiile ce au ca obiect crearea de

${ }^{36}$ Enzo Rossi, Patii successori:necessità o impedimento?, Ed. Utet Giuridica, 2017,p.177

37 Loi $n^{\circ}$ 2001-1135 du 3 décembre 2001 relative aux droits du conjoint survivant et des enfants adultérins et modernisant diverses dispositions de droit successoral, disponibilă la adresa: https://www.legifrance.gouv.fr/jorf/id/JORFTEXT000000582185 și

Loi $n^{\circ}$ 2006-728 du 23 juin 2006 portant réforme des successions et des libéralités , disponibilă la adresa:

https://www.legifrance.gouv.fr/loda/id/JORFTEXToooo00637158/?isSuggest=true.

38 François Terré, Yves Lequette ; Sophie Gaudemet, Droit civil : Les successions. Les libéralités, 4e édition, ed. Dalloz, 2014, p.603.

39

Disponibil

la

adresa:

https://www.legifrance.gouv.fr/codes/section lc/LEGITEXTooooo6070721/LEGISCTAooo 006150238/1804-03-30/\#LEGISCTA000006150238.

$4^{0}$ Article 722 C.civ.fr. (Modifié par Loi $\mathrm{n}^{\circ} 2001-1135$ du 3 décembre 2001 - art. 18 JORF 4 décembre 2001 en vigueur le 1er juillet 2002) ):

\section{4}


drepturi sau renunțarea la drepturi asupra întregii sau asupra unei părți dintro succesiune viitoare nedeschisă sau asupra unui bun din aceasta, nu produc niciun efect în afară de cazurile în care ele sunt permise de lege. Sunt create noi pacte de familie și este extins câmpul de aplicare a celor deja permise: clauza comercială din convenția matrimonială ( art. 1390-1392 C.civ. fr.) prin care soțul supraviețuitor poate păstra fondul de comerț, clientela civilă sau exploatarea agricolă, renunțarea anticipată la acțiunea în reducțiune, continuarea societății de persoane cu anumiți moștenitori, liberalitățile graduale $^{41}$ (art.1048 C.civ.fr.42). Toate acestea înclină balanța, în ciuda principiului enunțat, spre consacrarea succesiunii contractuale, alături de cea testamentară, însuşi noul articol 721 C. civ. fr. ${ }^{43}$ precizând că succesiunile se deferă în temeiul legi numai dacă defunctul nu a dispus prin liberalităţi.

\footnotetext{
'Les conventions qui ont pour objet de créer des droits ou de renoncer à des droits sur tout ou partie d'une succession non encore ouverte ou d'un bien en dépendant ne produisent effet que dans les cas où elles sont autorisées par la loi." disponibil la adresa: https://www.legifrance.gouv.fr/codes/section lc/LEGITEXTo00006070721/LEGISCTA000 006136266/2020-01-01/\#LEGIARTIO00006430700.

${ }^{41}$ Phipippe Malaurie, Laurent Aynés, Les successions. Les Libéralités, 6e édition, LGDJ, 2014, p. 340 , pct. 644 .

42

Disponibil

la

adresa:

https://www.legifrance.gouv.fr/codes/section lc/LEGITEXTo00006070721/LEGISCTA000 006150553/2020-01-01/\#LEGISCTA00000615055.

43 Article 721 C.civ.fr. (Modifié par Loi $\mathrm{n}^{\circ}$ 2001-1135 du 3 décembre 2001 - art. 18 JORF 4 décembre 2001 en vigueur le 1er juillet 2002):

"Les successions sont dévolues selon la loi lorsque le défunt n'a pas disposé de ses biens par des libéralités.

Elles peuvent être dévolues par les libéralités du défunt dans la mesure compatible avec la réserve héréditaire." disponibil la adresa: https://www.legifrance.gouv.fr/codes/section lc/LEGITEXTooo006070721/LEGISCTA0oo 006136266/2020-01-01/\#LEGIARTIO00006430700.
}

\section{5}


În Catalunia, Codului civil Catalan este modificat prin Legea 10/200844, care aduce schimbări fundamentale pentru pactele succesorale, o materie ce este acum desprinsă de forma originară a convențiilor matrimoniale şi plasată între instrumentele de planificare succesorală45. Succesiunea se transmite pe cale testamentară, prin desemnarea unui sau mai multor moștenitori ( art. 421-1 până la art. 429-15 C.civ.cat) , prin intermediul unui pact succesoral încheiat de autor (succesiune contractuală art.431-1 până la 444-1 C.civ.cat) sau în temeiul legii, în lipsa manifestării autorului de a dispune fie prin testament, fie prin pact succesoral ( art. 441-1 până la art. 444-1 C.civ.cat). Pot fi declarate valabile numai pactele succesorale ce au ca obiect bunuri determinate din succesiune (art. 431-29 și art. 431-30 C.civ.cat), $\mathrm{nu}$ şi cele care privesc succesiunea ca o universalitate. Fiind scoase din cadrul convențiilor matrimoniale, pactele succesorale nu mai sunt supuse condițiilor de formă prevăzute pentru acestea şi nici nu mai sunt rezervate soților sau viitorilor soți. Ele pot fi încheiate de toate persoanele unite printr-o legătură stabilă de tipul parteneriatului sau chiar de rudele de sânge în linie dreaptă, indiferent de grad, precum şi de colaterali, până la gradul patru ( art. 431-2 C.civ.cat.).

\section{Terminologie utilizată. Tipuri de pacte}

Încă din anul 2009, Comisia Europeană, demarând procesul de armonizare a normelor conflictuale și de procedură în materia succesiunilor internaționale, a constatat că una dintre sursele dificultăților o constituie și

44 Ley 10/2008, de 10 de julio, del libro cuarto del Código Civil de Cataluña, relativo a las sucesiones, disponibil la adresa: https://www.boe.es/eli/es-ct/1/2008/07/10/10/con 45 Susana Navas Navarro, op.cit, p. 107. 
divergențele ce există cu privire la mijloacele de anticipare succesorală în statele membre. Chiar dacă testamentul este cunoscut în toate aceste state, nu acelaşi lucru se poate spune despre testamentele conjuncte sau reciproce, ori despre instrumentele de anticipare mai elaborate ${ }^{46}$. Un impediment în cazul unei succesiuni internaționale poate să rezulte din încheierea un pact succesoral valabil într-un alt stat decât cel în care se desfăşoară procedura succesorală, stat de destinație care are o reglementare diferită sau care nu recunoaşte pactul respectiv ca fiind valabil. Diversitatea în reglementarea materială naţională este însoțită şi de o diversitate terminologică- pact succesoral, pact asupra unei succesiuni viitoare, pact asupra unei succesiuni nedeschise. Unul dintre scopurile demersului nostru este de a demonstra că noțiunea de pact asupra unei succesiuni viitoare, în înțelesul și în scopul aplicării RES, este diferită de noțiunea corespondentă din dreptul material. Regulamentul european utilizează termenul de pact asupra unei succesiuni viitoare, agreement as to succession, pacte successoral, pacto sucesorio, Erbvertrag47. Sub imperiul Codului civil 1864, textele articolelor vorbeau despre renunțare, învoială, iar termenul de pact asupra unei succesiuni nedeschise sau pact asupra unei succesiuni vïtoare era utilizat în doctrină48, preluat din dreptul roman. $\mathrm{O}$ dată cu intrarea în vigoare a noului Cod Civil, art. 956 C.civ. vorbește despre actele juridice având ca obiect drepturi eventuale asupra unei moșteniri nedeschise încă. În ordinea internă română,

${ }^{46}$ Disponibil la adresa: https://data.consilium.europa.eu/doc/document/ST-14722-2009-ADD2/fr/pdf, p.3, pct. 2.1.1.

47Disponibil la adresa: https://eur-lex.europa.eu/legalcontent/EN/TXT/HTML/?uri=CELEX:32012R0650\&from=RO

48 Mihail Eliescu, Curs de succesiuni, Editura Humanitas, 1997, București, p.36; Matei B. Cantacuzino, Elementele dreptului civil, Ed. All Educational, 21998,p. 404; Francisc Deak, Tratat de drept succesoral, Ediția a II-a, Ed. Universul Juridic, 2002, p. 289; Dan Chirică, Tratat de drept civil. Succesiunile și liberalitățile, Ed. C.H. Back, București, 2014, p. 378. 
problematica anticipării succesorale are o evoluție istorică liniară, interdicția fiind instituită în Codul civil 1864 şi menținută în Codul civil actual. Art. 965 alin.2 C.civ. 1864 interzicea orice renunțare la o succesiune care nu este deschisă, precum și orice învoire cu privire la o astfel de succesiune, chiar şi în cazul în care cel despre a cărui succesiune este vorba și-ar fi dat acordul sau ar fi participat la încheierea acestui act. Textul, plasat în materia contractuală, este dedicat obiectului contractului şi nu face altceva decât să preia interdicţia stipulată în Codul civil napoleonian ca o luptă împotriva obiceiurilor feudale și a dreptului de primogenitură. De altfel, având în vedere practica răspândită a instituirii contractuale prin intermediul contractului de căsătorie ${ }^{49}$, art. 702 C.civ. 1864 interzice ca într-un asemenea contract să fie incluse renunțări la succesiunea unei persoane în viață sau înstrăinări ale drepturilor eventuale ce ar putea fi dobândite dintr-o succesiune nedeschisă. Pentru a întări această regulă, nu este permis soților să modifice (art. 1225 și art. 1226 C. civ. 186450) drepturile pe care legea le dă soțului supraviețuitor în titlurile IX și X din Cartea I, nici să încheie vreo convenție sau renunțare ce ar avea ca obiect schimbarea ordinii legale a succesiunilor între ei şi descendenții lor. La intrarea în vigoare a Decretului nr. 32/31.01.1954 pentru punerea în aplicare a Codului Familiei aceste texte sunt abrogate expres (art. 49), fiind desființate toate regimurile matrimoniale convenționale, inclusiv regimul dotal. Dreptul roman prohibea pactele asupra succesiunilor viitoare din motive diferite, în funcție de obiectul pactului, cel mai puternic fiind acela că, prin încheierea pactului, lua naștere dorința morții unei persoane în viață:votum mortis

\footnotetext{
49 Instituirea contractuală, denumită în Codul civil 1864 donație de bunuri viitoare, era actul juridic prin care o persoană se obligă într-un contract să lase, la decesul său, o parte sau întregul său patrimoniu, unei alte persoane, care este instituit succesor prin intermediul unui contract.

C. Hamangiu, I. Rosetti Bălănescu, Al. Băicoianu, op.cit., p. 648, pct.1555.

$5^{\circ}$ Codicele Civil, adnotat cu jurisprudența română, op.cit., p.912
} 
captandae $^{51}$. Pactele de hereditates tertii erau nule pentru lipsa obiectului contractului, dar şi pentru caracterul lor imoral. Pactele de non succedendo începeau să fie mai degrabă admise, deoarece nu implicau o presupusă dorință a morții autorului succesiunii. Petrus Placentius în secolul al XII-lea şi Bonifaciu al VIII-lea (1299) validează acest tip de pacte atunci când erau însoțite de un jurământ $5^{2}$, ce le absolvea de încălcarea regulile moralei. Pactele de succedendo, prin care se instituia un moștenitor, erau interzise în dreptul roman pentru că dădeau naștere unor obligații irevocabile pentru cel despre a cărui moștenire era vorba, încălcând valoarea fundamentală a libertăţii de a testa. Aceste argumente fuseseră invocate și o dată cu adoptarea Codului civil român la 1864, prin preluarea art. 1130 C.civ. 1804, dar autorii moderni53 le considerau deja perimate; singurele elemente care mai puteau pleda pentru menținerea interdicției erau conservarea libertății de a testa și revocabilitatea testamentului. Autori contemporani, pentru a sublinia lipsa de actualitate a acestor considerente, exemplifică numeroase alte instituții care ar putea să fie abrogate pe motiv că ele atrag dorința morții unei persoane54- începând cu întreaga construcție a succesiunii氵5 legale şi ajungând până la asigurarea de viață, constituirea unui uzufruct sau a unei rente viagere.

Respectând filonul tradiției romane, în sistemele de drept care plasează interdicția pactelor asupra unei succesiuni viitoare ca pe un element central al ordinii publice succesorale, modul de reglementare al acesteia se

\footnotetext{
${ }^{51}$ Mihail Eliescu, op.cit., p.37

52 Jean-Philippe Lévy, André Castaldo, op.cit., p. 1318, pct. 942

53 Mihail Eliescu, op.cit., p. 37; Matei Cantacuzino, op.cit., p. 404 aprecia că doar elementele economice mai pot justifica astăzi această interdicţie, ceea ce ar explica si faptul că încetul cu încetul legiuitorul scoate diverse pacte de sub incidenta acesteia.

54 Philippe Malaurie, Laurent Aynés, op.cit, p. 368 şi urm..

55 François Terré, Yves Lequette, Sophie Gaudemet, op.cit., p. 604, pct. 686.
} 
bazează pe aplicarea unei metode obiective, care exclude orice cercetare intențională sau psihologică56. Articolul 956 C.civ. sancționează cu nulitatea absolută, atunci când prin lege nu se prevede altfel, toate actele juridice care au ca obiect drepturi eventuale asupra unei moșteniri nedeschise încă, precum actele prin care se acceptă moștenirea sau se renunță la aceasta, înainte de deschiderea ei, ori actele prin care se înstrăinează sau se promite înstrăinarea unor drepturi care s-ar putea dobândi la deschiderea moștenirii. Sunt astfel oprite actelor juridice asupra unei moșteniri nedeschise, viitoare ${ }^{57}$. Condițiile pentru ca interdicția să opereze nu sunt modificate față de vechea reglementare, dar noua redactare beneficiază de claritate prin suprimarea termenului anterior de pact, în care erau incluse, de inspiratie romană, și actele unilaterale. Din moment ce interdicția actelor juridice având ca obiect succesiuni viitoare este consacrată într-un articol dedicat obiectului contractului, se confirmă faptul că cercetarea cauzei și, implicit, a moralității acesteia în cazul unui asemenea act este abandonată. Menținerea interdicției pactelor succesorale apare mai degrabă expresia unei opțiuni legislative, prin care sunt protejate în principal libertatea și revocabilitatea ultimei voințe a unei persoane, considerentele morale fiind desuete.

Paleta drepturilor succesorale în Europa se caracterizează printr-o funcționare diferită a interdicției pactelor succesorale atât în raport de obiectul acestora: bunuri determinate sau succesiunea privită ca universalitate, cât şi în funcție de efectele acestora: pacte abdicative, dispozitive sau constitutive. Țările care consacrau la începutul secolului al XX-lea principiul interdicției pactelor succesorale prevăd astăzi excepții de la

\footnotetext{
${ }^{6}$ Philippe Malaurie, Laurent Aynés, op.cit., p. 369, pct. 687.

57 Francisc Deak, Romeo Popescu, op.cit., p. 208
} 
regula generală, recunoscând validitatea anumitor categorii de pacte succesorale, în principal a celor care au ca obiect bunuri determinate, cum ar fi cazul Spaniei ${ }^{8}$, Franței sau Belgiei. Dintre acestea însă doar Catalunia plasează în mod expres succesiunea contractuală între modurile de transmitere a succesiunii, celelalte menținând dihotomia clasică între succesiunea legală şi cea testamentară, cu accent pe una dintre acestea.

\section{Conținutul noțiunii de pact asupra unei succesiuni viitoare în RES.}

Regulamentul (UE) nr. 650/2012, prin modul de reglementare a pactelor succesorale se prezintă ca o veritabilă poartă de intrare a acestora în ordinea juridică a statului de destinație, care receptează de multe ori o instituție pe care nu o cunoaște în ordinea internă, dar pe care este chemat să o valideze cu ajutorul instrumentelor conflictuale pe care normativul european i le pune la dispoziție chiar în acest scop, în cadrul unei succesiuni internaționale. Nu este vorba de o simplă mobilitate a cetățenilor, deoarece aceștia circulă însoțiți de elemente fundamentale ale culturii juridice, consemnate în actele pe care le-au încheiat. Acestea au aptitudinea de a deveni, în timp, izvoarele unei noi ordini juridice, deoarece concepte juridice străine se bucură de acceptare şi chiar de recunoaştere, dincolo de statul lor de origine. Data de 17 august 2015 poate fi considerată un punct de referință, începutul unei circulații speciale a pactelor succesorale, care sunt validate prin intermediul normelor conflictuale și care produc efectele stabilite de

\footnotetext{
$5^{8}$ Sergio Cámara Lapuente, Freedom of Testation, Legal Inheritance Rights and Public Order under Spanish Law, în The Law of Succession: Testamentary Freedom, European Perspectives, Europa Law Publishing, 2011, p. 294-296
} 
legea care le guvernează, dincolo de teritoriul statului lor de origine. Ceea ce facilitează incluziunea lor într-o ordine străină prohibitivă este atât recunoașterea valabilităţii lor prin aplicarea art. 25 RES59 într-un stat ce le respinge pe plan intern, cât și principiul acceptării actelor autentice încheiate în materie succesorală în statele membre ( art. 59 RES $^{60}$ ).

59 Articolul 25 RES:" Pactele asupra unei succesiuni viitoare

(1) Un pact asupra unei succesiuni viitoare referitor la succesiunea unei persoane este reglementat, în privința admisibilității sale, a condițiilor de fond ale acestuia, a caracterului obligatoriu între părți și a condițiilor pentru desfacerea sa, de legea care, în temeiul prezentului regulament, ar fi fost aplicabilă succesiunii persoanei respective, în cazul în care aceasta ar fi decedat în ziua încheierii pactului.

(2) Un pact asupra unei succesiuni viitoare referitor la succesiunea mai multor persoane este admisibil numai dacă este admisibil în conformitate cu toate legile care, în temeiul prezentului regulament, ar fi fost aplicabile succesiunii tuturor persoanelor implicate, în cazul în care acestea ar fi decedat în ziua încheierii pactului.

Un pact asupra unei succesiuni viitoare care este admisibil în temeiul primului paragraf este reglementat, în ceea ce privește condițiile de fond, caracterul obligatoriu între părți și condițiile pentru desfacerea sa, de legea cu care are cea mai strânsă legătură dintre cele enumerate la primul paragraf.

(3) Fără a aduce atingere alineatelor (1) și (2), părțile pot alege ca lege care să reglementeze pactul asupra unei succesiuni viitoare, în ceea ce privește admisibilitatea, condițiile de fond, caracterul obligatoriu între părți și condițiile pentru desfacerea sa, legea pe care persoana sau una dintre persoanele al căror patrimoniu este vizat ar fi putut să o aleagă în conformitate cu articolul 22, în condițiile stabilite de respectivul articol." Disponibil la adresa: https://eurlex.europa.eu/legal-content/RO/TXT/?uri=celex\%3A32012Ro650

60 Articolul 59 RES: "Recunoașterea actelor autentice

(1) Un act autentic întocmit într-un stat membru are aceleaşi efecte probatorii în alt stat membru pe care le are în statul membru de origine sau efectele cele mai apropiate, cu condiția să nu contravină în mod vădit ordinii publice din statul membru în cauză.

Persoana care dorește să utilizeze un act autentic într-un alt stat membru poate solicita autorității care întocmește actul autentic în statul membru de origine să completeze formularul elaborat în conformitate cu procedura de consultare prevăzută la articolul 81 alineatul (2), care descrie efectele probatorii pe care actul autentic le produce în statul membru de origine.

(2) Orice contestare a caracterului autentic al unui act autentic se face în fața instanțelor judecătorești din statul membru de origine și se soluționează în temeiul dreptului statului respectiv. Actul autentic contestat nu produce efecte probatorii într-un alt stat membru atât timp cât acțiunea de contestare se află pe rolul instanței judecătorești competente. 
Regulamentul (UE) nr. 650/2012 definește în art. 3 alin. (1) lit.b) pactul asupra unei succesiuni viitoare ca fiind un acord, inclusiv un acord rezultat din testamente reciproce, care creează, modifică sau încetează, cu sau fără contraprestație, drepturi asupra patrimoniului sau patrimoniilor viitoare ale uneia sau mai multor persoane care sunt părți la acord. Pentru clarificarea și organizarea materiei, ținând cont de diversitatea reglementărilor naționale, în art. 3 alin. (1) lit. c) RES este definit și testamentul conjunctiv, ca fiind acel testament întocmit de două sau mai multe persoane într-un singur act. Potrivit aceluiași articol, noțiunea de dispoziție pentru cauză de moarte înglobează atât testamentele, cât și testamentele conjunctive, precum și pactele asupra unei succesiuni viitoare. Dispozițiile pentru cauză de moarte definite conform art. 3 alin. (1) lit. d) RES ce nu sunt pacte asupra unei succesiuni nedeschise precum și pactele asupra unei succesiuni viitoare privind succesiunea unei singure persoane vor fi considerate admisibile dacă îndeplinesc condițiile prevăzute de legea care ar fi guvernat succesiunea autorului dacă acesta ar fi decedat în ziua întocmirii dispoziției sau pactului (art. 24 alin. (1) RES și art. 25 alin. (1) RES). Pactul asupra unei succesiuni viitoare, definit de art. 3 alin. (1) lit. b) RES, referitor la succesiunea mai multor persoane este admisibil numai dacă este admisibil în conformitate cu toate legile care, în temeiul regulamentului, ar fi fost aplicabile succesiunii

(3) Orice contestare a actelor juridice sau a rapoartelor juridice înregistrate de un act autentic se face în fața instanțelor judecătorești competente în temeiul prezentului regulament și se soluționează în temeiul legii aplicabile în conformitate cu capitolul III. Actul autentic contestat nu produce efecte probatorii într-un stat membru, altul decât statul membru de origine, în ceea ce privește chestiunea contestată, atât timp cât acțiunea de contestare se află pe rolul instanței judecătorești competente.

(4) Dacă actele juridice sau raporturile juridice înregistrate într-un act autentic în materie de succesiuni sunt invocate pe cale accesorie înaintea unei instanțe judecătorești a unui stat membru, aceasta din urmă este competentă în materie." Disponibil la adresa: https://eurlex.europa.eu/legal-content/RO/TXT/?uri=celex\%3A32012Ro650 
tuturor persoanelor implicate, în cazul în care acestea ar fi decedat în ziua încheierii pactului ( art. 25 alin.2 RES). Dispozițiile regulamentului nu validează deci, cu titlu general, toate mecanismele de anticipare succesorală existente în statele membre. Dimpotrivă, sunt create două tipologii-cadru: pactele asupra unei succesiuni viitoare şi celelalte dispoziții pentru cauză de moarte, a căror admisibilitate cade în domeniul de aplicare a legii sau legilor succesorale ipotetice. Pentru celelalte instrumente de anticipare sau planificare succesorală, trebuie în concret determinat ${ }^{61}$ dacă vor fi analizate potrivit lex succesionis (o soluție mai coerentă) sau dacă vor fi lăsate pe tărâmul libertăţii contractuale promovate de art. 3 alin. (1) din Regulamentul Roma I ${ }^{62}$. Astfel că, numai acele testamente și testamente conjunctive valabile potrivit legii succesorale ipotetice sau legii alese de autor potrivit art. 24 alin. (2) $\mathrm{RES}^{63}$ și art. 22 alin. (1) RES ${ }^{64}$ vor avea aptitudinea de a-și produce efectele în succesiunea guvernată de legea unui stat care nu le admite în ordinea sa internă. Tot astfel, numai acele pacte asupra unei succesiuni viitoare, care

${ }^{61}$ Andrea Bonomi, Patrick Wautelet, Commentaire du Règlement no. 650/2012 du 4 juillet 2012, ed. Bruylant, 2014, p. 268

${ }^{62}$ Articolul 3 Regulamentul ( UE) nr. 593/2008 privind obligațiile contractuale: "Libertatea de alegere

â(1) Contractul este guvernat de legea aleasă de către părți. Această alegere trebuie să fie expresă sau să rezulte, cu un grad rezonabil de certitudine, din clauzele contractuale sau din împrejurările cauzei. Prin alegerea lor, părțile pot desemna legea aplicabilă întregului contract sau numai unei părți din acesta." Disponibil la adresa: https://eur-lex.europa.eu/legalcontent/RO/TXT/?uri=CELEX\%3A32008R0593

63 Art 24 alin. (2) RES: "Fără a aduce atingere alineatului (1), o persoană poate alege ca lege care să îi reglementeze dispoziția pentru cauză de moarte, cu privire la admisibilitatea și condițiile de fond ale acesteia, legea pe care acea persoană ar fi putut să o aleagă în conformitate cu articolul 22, în condițiile stabilite de respectivul articol."

64 Art. 22 alin. (1) RES: "O persoană poate să aleagă ca legea care să se aplice succesiunii sale în ansamblu său să fie legea statului a cărui cetățenie o deține în momentul alegerii legii sau la data decesului." 
îndeplinesc criteriile prevăzute în art. 3 alin.(1) lit. c) RES și sunt valabile potrivit legii sau legilor succesorale ipotetice sau legii alese de autor potrivit art. 25 alin.(3) RES ${ }^{65}$ şi art. 22 alin.(1) RES, vor avea aptitudinea de a-şi produce efectele în succesiunea guvernată de legea unui stat care nu le admite în ordinea sa internă.

Pornind de la elementele esențiale ale definiției pactelor asupra unei succesiuni viitoare trebuie clarificate două aspecte: care sunt tipurile abstracte de pacte ce intră în domeniul de aplicare al RES şi beneficiază de aplicarea favorabilă a normei conflictuale din art. 25 RES și care sunt diferențele care demonstrează că această noțiune nu corespunde în totalitate cu conținutul celei care este prohibită în anumite drepturi naționale.

În primul rând, pentru a vorbi de un pact succesoral în sensul RES, transmisiunea trebuie să corespundă noțiunii de succesiune privind patrimoniul unei persoane decedate. În regulament succesiunea beneficiază mai mult de o enumerare a formelor pe care le îmbracă, decât de o definiție propriu-zisă. Potrivit art. 3 alin. (1) lit .a) RES prin succesiune se înțelege: „succesiunea privind patrimoniul unei persoane decedate şi acoperă orice formă de transfer de bunuri, drepturi și obligații pentru cauză de moarte, fie că este vorba de un act voluntar de transfer, sub forma unei dispoziții pentru cauză de moarte, fie de un transfer sub forma succesiunii ab intestat". Regulamentul acoperă toate formele de transmisiune pentru cauză de moarte, recunoscând transmiterea contractuală alături de succesiunea testamentară și de cea legală, deoarece în noțiunea-cadru de dispoziție pentru cauză de

\footnotetext{
65 Art. 25 alin.(3) RES: "Fără a aduce atingere alineatelor (1) și (2), părțile pot alege ca lege care să reglementeze pactul asupra unei succesiuni viitoare, în ceea ce privește admisibilitatea, condițiile de fond, caracterul obligatoriu între părți și condițiile pentru desfacerea sa, legea pe care persoana sau una dintre persoanele al căror patrimoniu este vizat ar fi putut să o aleagă în conformitate cu articolul 22, în condițiile stabilite de respectivul articol."
} 
moarte intră atât testamentele, inclusiv cele conjunctive, cât și pactele succesorale. Deși este posibil ca lex succesionis să nu recunoască decât succesiunea legală și pe cea testamentară, succesiunea contractuală ar putea, în a numite condiții, să producă efecte în ordinea internă, în alte cazuri decât cele permise, eventual, de aceasta. Nefiind o normă materială, art. 3 alin.(1) lit. a) RES nu stabilește o ierarhie a modalităților de transmitere a succesiunii, însă în conținutul noțiunii autonome de succesiune nu intră toate actele voluntare de transfer, ci numai acelea ce corespund noțiunii de dispoziție pentru cauză de moarte. Există mai multe mecanisme juridice, în principal inspirate din sistemul de common-law, prin intermediul cărora se realizează transferul unui bun pentru cauză de moarte, de la constituant la beneficiar, fără ca acestea să fie înglobate în definiția transferului succesoral. În această categorie- satelit care gravitează ${ }^{66}$ în jurul instituției succesiunii sunt tradițional incluse clauza de supraviețuire sau retroactivitatea transferului de proprietate și clauza de tontină din dreptul francez și belgian. Toate actele juridice încheiate în timpul vieții, cu intenția ca dispunătorul să transfere, la moartea sa, beneficiarului desemnat altfel decât prin succesiune, dreptul de proprietate asupra unui bun ce îi aparține sau de a crea drepturi sau interese în favoarea acestuia asupra bunurilor pe care le deține au fost incluse într-o categorie separată denumită succession substitutes ${ }^{67}$. Pentru aceste transferuri, ce produc efecte comparabile cu succesiunea, nu se pot aplica

66 Esther Bendelac, Le transfert de biens au décês autrement que par succession en droit international privé. Le choix de la loi applicable aux institutions d'Estate planning, Ed. Bruylant, Bruxelles, 2016, p. 266.

67 Jeffrey Talpis, Succession Substitutes, Collected Courses of the Hague Academy of International Law, vol. 356, 2011, p. 199. "A succession substitute is a juridical act entered into by the decedent during his/her lifetime, with the intent to transfer property or to create rights or interests in property owned or owned by him/her in substancem at his/her death to or in favour of a designated beneficiary otherwise than by succession. " 
normele conflictuale conținute în RES. Propunerile de reglementare formulate ${ }^{68}$ țin cont de natura lor duală: izvorul contractual le conduce spre libertatea de a alege legea aplicabilă, dar efectele față de terți care le apropie de efectele succesorale, ar impune respectarea drepturilor moștenitorilor rezervatari sau ale altor categorii de moștenitori ce sunt protejați conform lex successionis.

În al doilea rând, succesiunea în care sunt analizate pactele asupra unei succesiuni viitoare trebuie să fie o succesiune internațională. Spre deosebire de art. 1 alin. (1) din Regulamentul Roma I, art. 1 alin. (1) din Regulamentul Roma II și art.1 alin.(1) din Regulamentul Roma III, care trimit explicit la existența unui conflict de legi, regulamentul european privind succesiunile nu impune explicit în corpul cu valoare normativă nici condiția ca succesiunea să aibă un caracter internațional, nici ca situația de succesiune să conducă la crearea unui conflict de legi. Însă, din redactarea considerentelor (1) și (7) RES ${ }^{69}$ rezultă că scopul acestei noi reglementări este de a înlătura dificultățile pe care le au resortisanții europeni în a-şi exercita

http://curia.europa.eu/juris/document/document.jsf;jsessionid=55DCA42ACB652D1A4131D 4540B4988C9?text=\&docid=228675\&pageIndex=o\&doclang=ro\&mode=lst\&dir $=\& o c c=$ first \&part=1\&cid=6265846p. 178 și urm.

69 Considerentul (1) RES: "Uniunea şi-a stabilit obiectivul de a menține şi a dezvolta un spațiu de libertate, securitate și justiție, în cadrul căruia este asigurată libera circulație a persoanelor. Pentru instituirea treptată a acestuia, Uniunea urmează să adopte măsuri privind cooperarea judiciară în materie civilă având implicații transfrontaliere, în special atunci când sunt necesare pentru buna funcționare a pieței interne."

Considerentul (7) RES: "Funcționarea corespunzătoare a pieței interne ar trebui facilitată prin eliminarea obstacolelor din calea liberei circulații a persoanelor care se confruntă în prezent cu dificultăți în exercitarea propriilor drepturi în contextul unei succesiuni cu elemente de extraneitate. În spațiul european de justiție, cetățenii trebuie să își poată organiza din timp succesiunea. Trebuie garantate într-un mod eficient drepturile moștenitorilor și legatarilor, ale altor persoane apropiate defunctului, precum și ale creditorilor succesiunii." 
drepturile, în contextul unor succesiuni cu implicații transfrontaliere ${ }^{70}$. Pentru a ne plasa în domeniul de aplicare a RES, textul nu ne oferă niciun răspuns cu privire la conținutul implicațiilor transfrontaliere. Am putea integra în acestea numai situațiile în care există sau ar putea să existe un conflict de legi, sau am putea adăuga toate ipotezele în care este prezent un element internațional. Elementul internaţional ar putea să fie, la rândul său, mai strâns legat de succesiune, sau să indice o legătură mai slabă cu aceasta; ar putea să se refere la plasarea unor bunuri într-un alt stat decât cel în care se desfăşoară procedura de succesiune, la reședinţa obişnuită a unuia dintre moştenitori, la locul unde a fost întocmită dispoziția pentru cauză de moarte sau la legea aleasă pentru a se aplica succesiunii în ansamblul său. Elementul ce generează implicaţiile transfrontaliere ar putea să existe la data deschiderii succesiunii- cum ar fi ultima reședință obişnuită a celui decedat într-un alt stat decât cel unde se află bunurile, sau ar putea să nu mai existe la data deschiderii succesiunii, dar să fi existat la un moment anterior, cu aptitudinea de a genera un conflict de legi (cum ar fi situaţia în care succesiunea este deschisă ca o succesiune pur națională, dar la data întocmirii unui testament defunctul avea reședința obişnuită într-un alt stat, motiv pentru care este necesară aplicarea art. 24 RES şi apelul la legea succesorală ipotetică). O explicaţie ar putea exista pentru modalitatea în care regulamentul evită să definească expres natura internațională a succesiunii, şi anume faptul că existența condiției exprese a caracterului internațional ar putea genera dificultăți și îndoielile în circumstanțe în care totuși regulamentul trebuie să se aplice ${ }^{11}$. Apreciem că necesitatea prezenței unui element internaţional sau

\footnotetext{
70 În varianta în limba engleză este utilizată sintagma: having cross-border implications.

${ }^{71}$ Alfonso-Luis Calvo Caravaca, Angelo Davì and Heinz-Peter Mansel, The EU Succession Regulation, A Comentary, Cambridge University Press, 2016 p. 27.
} 
aptitudinea situației de succesiune de a avea implicații transfrontaliere trebuie interpretată în concret, în raport de setul de norme a cărui aplicare este luată în considerare. Astfel, pentru a fi aplicabile dispozițiile capitolelor IV sau V din RES este suficient ca hotărârea judecătorească, actul autentic sau tranzacția judiciară să fie utilizate pentru a-și produce efectele într-un alt stat membru decât cel în care au fost pronunțate sau încheiate. Tot astfel, pentru a fi aplicabile dispozițiile privind Certificatul european de moștenitor este suficientă îndeplinirea condițiilor referitoare la scopul său determinat de art. $63 \mathrm{RES}^{72}$. În cauza C-80/1973, Curtea de Justiție a Uniunii Europene a fost chemată să stabilească dacă o anumită succesiune este o succesiune cu elemente transfrontaliere în înțelesul RES, fiind necesar ca acest regulament să fie aplicat ${ }^{74}$.Curtea a învederat "că Regulamentul nr. 650/2012 a fost

72 Art. 63 RES: " 1) Certificatul este destinat utilizării de către moștenitori, de către legatari cu drepturi directe la succesiune și de către executori testamentari sau administratori ai patrimoniului succesoral care trebuie să își dovedească într-un alt stat membru statutul sau să își exercite dreptul respectiv de moştenitor sau legatar şi/sau atribuțiile de executor testamentar sau administrator al patrimoniului succesoral.

(2) Certificatul poate fi utilizat, în special, pentru a proba unul sau mai multe dintre următoarele:

(a)statutul și/sau drepturile fiecărui moștenitor sau, după caz, ale fiecărui legatar menționat în certificat și cotele-părți respective din patrimoniul succesoral;

(b)atribuirea unui bun anume sau a anumitor bunuri care fac parte din patrimoniul succesoral moștenitorului/moștenitorilor sau, după caz, legatarului menționat (legatarilor menționați) în certificat;

(c)atribuțiile persoanei menționate în certificat ca executor testamentar sau ca administrator al patrimoniului succesoral. "

73http://curia.europa.eu/juris/document/document.jsf;jsessionid=55DCA42ACB652D1A413 1D4540B4988C9?text $=\& d o c i d=228675 \&$ pageIndex $=0 \&$ doclang $=$ ro\&mode $=1$ st \&dir $=\& o c c=$ fir st\&part $=1 \&$ cid $=6265846$.

74 "În aceste condiții, Lietuvos Aukščiausiasis Teismas (Curtea Supremă a Lituaniei) a hotărât să suspende judecarea cauzei și să adreseze Curții următoarele întrebări preliminare:

„1) Trebuie să se considere că, într-o situație precum cea din speță - în care un resortisant lituanian, a cărui reședință obișnuită la data decesului său se afla eventual în alt stat membru, dar care, în orice caz, nu a rupt niciodată legăturile sale cu țara natală și care, printre altele, a 
adoptat în temeiul articolului 81 alineatul (2) TFUE, care vizează numai materia civilă cu incidență transfrontalieră". În decizia menţionată, CJUE arată că succesiunea poate fi considerată ca fiind în domeniul de aplicare a RES fie datorită plasării ultimei reședințe obișnuite a defunctului într-un alt stat decât cel în care se deschide succesiunea (paragraful 36), fie prin incidența unui alt element referitor la aceasta, deoarece 75 "Regulamentul nr. 650/2012 vizează, în mod neexhaustiv, alte împrejurări care pot demonstra existența unei succesiuni care implică mai multe state membre." Având și argumentația Curții, afirmăm că, pentru aplicarea RES, gradul de internaționalitate cerut pentru a caracteriza succesiunea fluctuează în raport de norma invocată. Pentru materia ce ne interesează, caracterul internațional ar putea rezulta în principal din încheierea pactului succesoral într-un alt stat decât cel în care se desfăşoară procedura de succesiune, sau din faptul că cel despre a cărui succesiune este vorba a desemnat în mod expres legea care guvernează admisibilitatea pactului și aceasta aparține unui alt stat decât cel în care se află reședința sa obişnuită în momentul încheierii pactului sau în momentul deschiderii succesiunii.

făcut anterior decesului un testament în Lituania şi a lăsat toate bunurile moștenitorului său, cetățean lituanian, iar la momentul deschiderii succesiunii s-a stabilit că întregul patrimoniu succesoral este format dintr-un bun imobil situat în Lituania, și un resortisant al celuilalt stat membru în cauză, soțul supraviețuitor, și-a exprimat în mod clar intenția de a renunța la toate drepturile asupra patrimoniului succesoral, nu a participat la procedura judiciară inițiată în Lituania și a fost de acord cu competența instanțelor lituaniene și cu aplicarea dreptului lituanian -, succesiunea pentru cauză de moarte are elemente de extraneitate în sensul Regulamentului nr. 650/2012 şi este necesar să i se aplice acest regulament? 74 ", disponibil la adresa:

http://curia.europa.eu/juris/document/document.jsf;jsessionid=55DCA42ACB652D1A4131D4540B49 $\underline{88 \mathrm{C} 9}$ ?text $=\&$ docid $=228675 \&$ pageIndex $=0 \&$ doclang $=$ ro \&mode $=1$ st $\&$ dir $=\&$ occ $=$ first $\&$ part $=1 \&$ cid $=626$ $\underline{5846}$

75 Paragraful 42 și 43 din Decizia CJUE în cauza C-80/19. 
În cele din urmă, actul juridic analizat trebuie, în conformitate cu art. 3 lit. b) RES să fie un acord inclusiv un acord rezultat din testamente reciproc; să creeze, să modifice sau să stingă, cu sau fără contraprestație, drepturi asupra patrimoniului sau patrimoniilor viitoare ale uneia sau mai multor persoane; iar persoanele despre a căror succesiune este vorba trebuie să fie părți ale acestui acord. Din prima condiție rezultă că din noțiunea europeană sunt excluse pactele de hereditates tertii. Asemenea mecanisme juridice de anticipare succesorală vor fi considerate în continuare ca pacte succesorale în ordinea juridică internă, dar nu vor constitui pacte asupra unei succesiuni viitoare în sensul RES, deci nu vor beneficia de norma conflictuală conținută în art. 25 RES. Ele nu vor rămâne într-un spațiu nereglementat, ci vor urma domeniul de aplicare al lex successionis ${ }^{76}$ care va hotărâ cu privire la admisibilitatea lor. Deşi va fi apreciat ca un pact succesoral în ordinea internă catalană, acordul dintre soți sau parteneri stabili care renunță la legitima la care ar avea dreptul în succesiunea copiilor comuni, precum și pactul de supraviețuire, în care supraviețuitorul renunță la ceea ce i-ar putea reveni din succesiunea ab intestat a copilului său minor mort, reglementate de art. 45126 alin.2 lit. a) şi b) C.civ.cat., nu vor îndeplini condițiile pentru a fi considerate pacte asupra unei succesiuni viitoare în înțelesul RES. În ceea ce privește pactele de non succedendo, ele vor fi admise ${ }^{77}$ în măsura în care presupun acordul autorului succesiunii şi a prezumtivilor beneficiari. Pactul abdicativ unilateral nu îndeplinește condițiile pentru a fi considerat un pact asupra unei succesiuni viitoare în sensul RES, dar admisibilitatea sa va fi

${ }^{76}$ Art. 23 alin.2 RES nu enumeră exhaustiv aspectele reglementate de lex successionis,

77 Pentru o opinie contrară Bruno Barel, Il regulamento UE nr. 650/2012: una nuova prospettiva nelle successioni internazionali in Europa, Milano, 3 iunie 2013, lucrare prezentată în cadrul conferintei Proiectului Europa pentru Notari, Notari pentru Europa, p. 4 
supusă legii care se aplică succesiunii. Un prim exemplu ar fi acela al renunțării anticipate a moștenitorului rezervatar la dreptul de a cere reducțiunea unei liberalități în conformitate cu art. 929 C.civ. fr..$^{78}$ care nu produce efecte decât după ce a fost acceptat de autorul succesiunii 79 . Articolul 3 alin.(1) lit.b) RES nu impune cerința ca acordul autorului pactului și a beneficiarului să figureze în acelaşi înscris. De aceea, un acord între autorul succesiunii și prezumtivul moștenitor care renunță la unele drepturi asupra succesiunii poate interveni şi prin acte separate, cum ar fi ipoteza concretă a renunțării la drept în temeiul art. 929 C.civ. fr. În dreptul catalan, potrivit art. 451-26 C.civ.cat., ar putea fi validat ca pact succesoral conform RES, actul încheiat între copii și părinții lor, prin care aceștia din urmă renunță la legitima care le-ar putea reveni din moștenirea unuia dintre copiii lor predecedați, precum și acordul dintre ascendenți și descendenți, prevăzut într-un pact succesoral sau într-o donație, prin care descendentul care primește de la ascendentul său bunuri sau bani ca plată a viitoarei legitime renunță la posibilul supliment ${ }^{80}$. Pactul succesoral ce cade în domeniul RES

${ }^{78}$ Article 929 C.civ.fr.: „Tout héritier réservataire présomptif peut renoncer à exercer une action en réduction dans une succession non ouverte. Cette renonciation doit être faite au profit d'une ou de plusieurs personnes déterminées. La renonciation n'engage le renonçant que du jour où elle a été acceptée par celui dont il a vocation à hériter.

La renonciation peut viser une atteinte portant sur la totalité de la réserve ou sur une fraction seulement. Elle peut également ne viser que la réduction d'une libéralité portant sur un bien déterminé.

L'acte de renonciation ne peut créer d'obligations à la charge de celui dont on a vocation à hériter ou être conditionné à un acte émanant de ce dernier.", disponibil la adresa https://www.legifrance.gouv.fr

79 Ioana Olaru, Rezerva succesorală în dreptul intern şi în dreptul internaţional privat, Ed. Solomon, 2019, p. 194

80 Article 451-26 CCCat:Renúncia a la llegítima futurapactul de non succedendo, în Ioana Olaru, Rezerva succesorală în dreptul intern și în dreptul internaţional privat, Ed. Solomon, 2019, p. 214 
implică obligatoriu participarea autorului succesiunii, ceea ce conferă un caracter irevocabil dispoziției sale. Intră în această categorie donația-partaj (în ciuda naturii sale mixte, contractuale), pactele succesorale globale din dreptul belgian, testamentele reciproce sau pactele succesorale din dreptul german. Acestea vor putea, cu respectarea condițiilor de valabilitate, să fie admise într-un stat membru care nu recunoaște în dreptul intern un asemenea pact.

\section{Concluzii}

Regulamentul european privind succesiunile are destinația de a asigura compatibilitatea normelor privind conflictul de legi și de competență aplicabile în statele membre în situațiile în care succesiunea prezintă implicații transfrontaliere. Prin noțiunile definite, succesiune, pact asupra unei succesiuni viitoare, dispoziție pentru cauză de moarte, nu se schimbă doar viziunea asupra transmisiunii succesorale în statele membre. Uneori autoritățile cu atribuții în procedurile de succesiune sunt în mod concret chemate să aplice instituții și să admită efectele unor instituții pe care ordinea lor internă nu le acceptă. În cazul drepturilor reale necunoscute de statul unde este situat bunul ${ }^{81}$, autoritățile judiciare din acest stat transformă dreptul real străin în cel mai apropiat drept real echivalent ce există în legislația statului de destinație. În cazul pactelor asupra unei succesiuni viitoare, admisibilitatea

\footnotetext{
${ }^{81}$ Art. 31 RES: "Adaptarea drepturilor reale În situația în care o persoană invocă un drept real la care este îndrituită în temeiul legii aplicabile succesiunii, iar în legislația statului membru unde este invocat dreptul real nu este prevăzut dreptul real în cauză, respectivul drept se adaptează, dacă este necesar și în măsura în care acest lucru este posibil, la cel mai apropiat drept real echivalent în temeiul legislației statului respectiv, luând în considerare obiectivele și interesele urmărite de dreptul real specific și efectele acestuia. "
} 
este asigurată prin intermediul normei conflictuale stabilite de art. 25 RES. Această concluzie este sprijinită de redactarea considerentului (49) RES ${ }^{82}$. Acceptarea în statele membre a drepturilor succesorale dobândite ca rezultat al unui pact asupra unei succesiuni viitoare este facilitată prin intermediul dispozițiilor din regulament care precizează care lege va reglementa admisibilitatea acestui tip de pact, condițiile de fond şi caracterul obligatoriu între părți, inclusiv condițiile pentru desfacerea sa. Acceptarea pactelor succesorale în condițiile de admisibilitate impuse de RES este consolidată şi de modul în care este rezolvată chestiunea acceptării actelor autentice emise în materie succesorală în statele membre. Având în vedere consecințele sale asupra libertății de voință a autorului succesiunii, materializate în lipsirea acestuia de atributul revocabilității unilaterale, forma autentică notarială este impusă cvasi-unanim pentru că oferă garanții proporționale cu efectele produse. Pactele asupra unei succesiuni viitoare sunt expres enumerate în considerentul (63) $\mathrm{RES}^{8_{3}}$ ca fiind acte juridice înregistrate de un act autentic supus circulaţiei, ale cărui efecte sunt acceptate în statele membre. Este

82 Considerentul (49) RES: " Pentru a facilita acceptarea în statele membre a drepturilor succesorale dobândite ca rezultat al unui pact asupra unei succesiuni viitoare, în prezentul regulament ar trebui să se precizeze care lege va reglementa admisibilitatea acestui tip de pact, condițiile de fond și caracterul obligatoriu între părți, inclusiv condițiile pentru desfacerea sa. $"$

83 Considerentul (63) RES: " Sintagma „actele juridice sau rapoartele juridice înregistrate de un act autentic" ar trebui interpretată ca o trimitere la conținutul pe fond înregistrat în actul autentic. Actele juridice înregistrate într-un act autentic ar putea fi, de exemplu, acordul dintre părți privind partajul succesoral sau repartizarea succesiunii, un testament, un pact asupra unei succesiuni viitoare sau o altă declarație de intenție. Rapoartele juridice ar putea fi, de exemplu, vocația succesorală a moștenitorilor sau a altor beneficiari, în funcție de legea aplicabilă succesiunii, stabilirea cotelor-părți respective ale acestora și a existenței unei rezerve succesorale sau orice alt element stabilit în temeiul legii aplicabile succesiunii. O parte care dorește să conteste actele juridice sau rapoartele juridice înregistrate într-un act autentic ar trebui să facă acest lucru în fața instanțelor judecătorești competente în temeiul prezentului regulament, care ar trebui să soluționeze contestarea în temeiul legii aplicabile succesiunii. "

\section{4}


adevărat că efectele actului juridic autentic nu se vor produce dacă ele contravin în mod vădit ordinii publice din statul membru în cauză, potrivit art. 59 alin.(1) RES. Instanțele din statele membre ar putea fi într-o zi chemate să se pronunțe cu privire la excepția de ordine publică internațională și în cazul pactelor asupra unei succesiuni viitoare ${ }^{84}$. Însă, aşa cum pactele succesorale din dreptul intern nu corespund totdeauna noțiunii de pact asupra unei succesiuni viitoare în înțelesul RES, nici ordinea publică internă ce interzice pactele asupra succesiunilor viitoare nu corespunde integral $\mathrm{cu}$ ordinea publică de drept internațional privat. Scopul regulamentului ar fi însă denaturat atunci când instanțele sau celelalte autorităţi competente ar aplica excepția de ordine publică refuzând să recunoască - sau, dacă este cazul, să accepte- sau să execute o hotărâre, un act autentic sau o tranzacție judiciară dintr-un alt stat membru, dacă în felul acesta ar încălca dispozițiile Cartei drepturilor fundamentale a Uniunii Europene, în special articolul 21, care interzice toate formele de discriminare ${ }^{85}$.

$\mathrm{Au}$ trecut mai mult de 150 de ani până când pactele asupra unei succesiuni viitoare să fie reprimite în ordinea succesorală internă. De la adoptarea Codului civil Napoleon și până la primele reforme succesorale din Franța, principiul interdicției a sprijinit conceptul de ordine publică internă. În dreptul românesc, instituirea contractuală a avut o viață și mai scurtă, iar posibilitățile de anticipare succesorală sub imperiul Codului civil 1864 au fost reduse. Prin adoptarea noului Cod Civil s-a lărgit paleta instrumentelor de planificare succesorală: acordul moștenitorilor în cazul unei înstrăinări sub rezerva uzufructului, uzului, habitației, întreținerii sau rentei viagere ( art.

\footnotetext{
84 Michel Grimaldi, Droit des successions, 7e édition, ed. LexisNexis, Paris, 2017,p. 287. 85 Considerentul (58) RES.
} 
1091 alin. (4) C. civ.), asigurarea de viață cu desemnarea unui terț beneficiar, donația partaj conjunctivă, clauza de preciput. Deși sunt excepții de la principiul interdicției actelor asupra unei succesiuni viitoare nedeschise, doar unele dintre acestea îndeplinesc condițiile pentru a fi considerate pacte asupra unei succesiuni viitoare în sensul RES. Se multiplică însă ipotezele în care pacte succesorale încheiate în statele membre ale Uniunii Europene sunt prezentate pentru a-și produce efectele într-o succesiune ce se soluționează în România. Influența acestora nu poate fi negată, chiar dacă admisibilitatea lor este limitată la succesiunile ce prezintă implicații transfrontaliere. Dar această receptare a unor noi instrumente juridice poate avea aptitudinea de a conduce în timp la o reformă a materiei pactelor succesorale, cu menținerea unui echilibru între tradiție și nevoile unei societăți europene moderne. 